\title{
ASPECTS CONCERNING INTERIM FINANCIAL REPORTING IN ROMANIA: STANDARDS AND REGULATIONS
}

\author{
Rotilă Aristița \\ "Vasile Alecsandri" University of Bacău, Romania \\ rotila11@yahoo.com
}

\begin{abstract}
The mechanisms employed for the communication of accounting information that is necessary for users in their economic decision-making process consist of the financial statements of an entity. All legal entities, no matter the domain of their activity, have the obligation to draw up annual financial statements for every completed financial year. For certain categories of entities, reporting obligations are also required for periods other than the annual reporting, throughout the financial year. It is the case of interim financial reporting. At the level of the international accounting framework, the aspects related to interim financial reporting are the subject of a separate standard, namely, IAS 34 Interim Financial Reporting. In Romania, the current system of accounting regulations concerning the annual financial statements comprises accounting regulations that comply with the European directives and which apply to the various categories of entities, on the one hand and, on the other, accounting regulations in line with the IFRS, which are applicable to other classes of entities from certain activity sectors. The accounting regulations that apply to each category refer to, among other things, the contents and the format of financial statements that have to be presented. Analysing the system of norms and regulations, this article identifies the requirements concerning interim financial reporting in Romania, with reference to the different types of entities.
\end{abstract}

\section{Keywords}

accounting regulations; financial statements; interim financial reporting; financial position; IFRS; European directives

\section{JEL Classification}

M41

\section{Introduction}

It is well known that the information produced by the accounting activity assists both the internal communication and the external communication of an entity. External communication, which makes the activity of the entity accessible to investors, the state, creditors, suppliers, clients and other legal entities or sole traders that might be interested, is ensured by means of the periodical information provided by financial statements (Rotilă, 2011). The International Financial Reporting Standards (IFRS) approach the subject of presenting general purpose financial statements that should be prepared annually by entities, as well as the aspects concerning interim financial reporting, but they do not establish which entities should publish interim financial reports, how frequently they should do it, or how soon after the end of a certain period. The International Accounting Standards Board (IASB) considers that these problems should be decided at the level of each country by governments, organisms for the regulation of securities, stock exchanges and professional accountancy organisms.

In Romania, all juridical persons, no matter the domain in which they activate or their size, are required to draw up annual financial statements for the completed financial year, an obligation stipulated by Accounting Law no. 82/1991 (Art. 28). For certain 
categories of entities, reporting obligations are also required for periods other than the annual reporting, throughout the financial year, in order to provide the information that is necessary for the institutional system of the state, for prudential supervisory purposes or with informative purposes that satisfy the needs of categories of users other than state institutions.

Given that at the present moment, in Romania, certain categories of entities have to apply regulations that comply with the IFRS for the preparation of annual and interim financial statements, we will further present synthetically the characteristic aspects concerning interim financial reporting from the perspective of the international accounting referential and, after classifying the categories of entities depending on the accounting regulations that apply to them, we will try to identify the requirements that are specific to interim financial reporting in Romania.

\section{Interim financial reporting in the international accounting referential}

At the level of the international accounting referential, the regulations concerning interim financial reporting are included in a separate standard, namely, 34 Interim Financial Reporting. As stated in the objective of this standard, IASB considers that a reliable and timely interim financial reporting improves the ability of investors, creditors and other users to understand the capacity of an entity to generate revenue and cash flows, as well as its financial condition and liquidity.

IAS 34 Interim Financial Reporting establishes the minimum components of an interim financial report, as well as the principles for the accounting recognition and measurement that should be applied for the preparation of an interim financial report. However, the standard does not establish any rule concerning which entities should publish interim financial reports, how frequently they should do it, or how soon after the end of an interim period, the IASB considers that these problems should be decided at the level of each country by governments, organisms for the regulation of securities, stock exchanges and professional accountancy organisms (IASB, 2011).

Nevertheless, IASB encourages entities whose debts or shares are traded publicly to publish interim financial reports at least twice a year and to publish them no later than 60 days after the end of the interim period (IAS 34, par.1).

An interim financial report is defined as a financial report that contains either a complete set of financial statements (as described in IAS 1 Presentation of Financial Statements) or a set of condensed financial statements for an interim period (a reporting period shorter than a full financial year).

The set of condensed financial statements proposed by IAS 34 as an alternative to the complete set presented in IAS 1 includes at least the following components:

- a condensed statement of financial position;

- a condensed statement of comprehensive income;

- a condensed statement of changes in equity;

- a condensed statement of cash flows;

- $\quad$ selected explanatory notes.

If an entity chooses to present a condensed set of financial statements, these shall contain at least each of the headings and each of the subtotals that were presented in the most recent annual financial statements together with the selected explanatory notes. IAS 34 lists a series of events and transactions for which information shall be included if this is relevant (IAS 34, par. 15B). Explanatory notes shall contain all the significant information so that the users could understand the changes in the financial position or the performance of the entity since the last annual report. If an entity chooses the complete set of financial statements for its interim financial report, the form and contents of these statements shall comply with the requirements described in IAS 1 Presentation of Financial Statements. 
As in the case of annual financial statements, interim financial statements should present comparative information, as follows:

- $\quad$ in the statement of financial position: the statement at the end of the interim period and the statement as of the end of the preceding financial year;

- $\quad$ in the statement of comprehensive income: the statement for the current interim period and the statement for the cumulative comprehensive income from the beginning of the current year to date; comparative statements for the comparable interim periods of the preceding financial year;

- $\quad$ in the statement of changes in equity and the statement of cash flows: the cumulative statement from the beginning of the current financial year to date; the cumulative statement for the comparable interim period of the preceding financial year;

For the preparation of interim financial statements, the entity shall apply the same accounting policies as in the case of annual financial statements, with the exception of changes in accounting policies that occur after the date of the most recent annual financial statements (in other words, since the beginning of the current financial year) and which will be reflected in the following annual financial statements. An entity's reporting frequency (annually, half-yearly or quarterly) should not affect the measurement of the annual results, so the measurement carried out for interim financial reporting should be conducted on a cumulative basis, from the beginning of the financial year to date.

We must also mention that, as far as the interim financial statements' compliance with IFRS is concerned, the same requirements are applied as in the case of annual financial statements, meaning that if the interim financial report of an entity is presented as conforming to the IFRS, then they should fulfil the requirements of all IFRS.

\section{The system of accounting regulations in Romania and the categories of accounting entities}

As it is known, the institution that is in charge of regulating accountancy (the issuing of norms and regulations in the accounting domain) in Romania is the Ministry of Public Finances. The accounting norms and regulations specific to certain areas of activity are proposed and issued by the institutions that have such attributions, with the approval of the Ministry of Public Finances (MPF), the National Bank of Romania-NBR (for the banking sector) and the Financial Supervisory Authority-FSA (for the capital markets sector, the insurance sector, the private pensions sector), which form an entire system concerning accounting regulations.

In Romania, all legal entities, irrespective of the domain of activity, have the obligation to draw up annual financial statements for every completed financial year, in compliance with implemented accounting regulations, an obligation that is stipulated by Accounting Law no. 82/1991 (Art. 28).

The current system of accounting regulations in Romania, with reference to the annual financial statements, contains both accounting regulations that conform to European directives specific to the various types of entities and accounting regulations that comply with IFRS and which are applicable to other categories of entities.

Accounting regulations that conform to the IFRS are applied in the present in Romania by the following categories of entities:

- companies whose securities are admitted for trading on a regulated market, the incident regulations being approved by Order of MPF no. 1286/2012;

- credit institutions, the incident regulations being approved by the Order of NBR no. 27/2010. 
Mention should be made that, starting with the fiscal year corresponding to 2015, in compliance with the provisions of the FSA Instruction no. 2/2014, regulations complaint with the IFRS will also be applied by the entities authorized, regulated and supervised by the FSA - the Financial Instruments and Investments Sector of (by financial investment firms, investment management firms, collective investment undertaking, central securities depositories, clearing house and market/system operators).

As far as the set of annual financial statements, for those entities that apply accounting regulations compliant with European directives, its components are those set out by the applicable accounting regulations, and for entities that apply accounting regulations that conform to the IFRS, the components are those prescribed by the IAS 1 Presentation of Financial Statements. Annual financial statements presented in compliance with the IFRS represent financial statements with a general scope as they are meant to satisfy the needs of the users who are not entitled to impose on an entity the preparation of reports that are adapted to their specific informative needs.

In order to ensure the information system of the state, the Ministry of Public Finances asks entities that apply accounting regulations in compliance with the IFRS to present annual accounting reports at the territorial units of the Ministry of Public Finances. The standard form, contents and submission deadline for these reports are established by regulations issued, depending on the case, by the Ministry of Public Finances for economic agents, or by the NBR for credit institutions. In compliance with the Order of NBR no. 1/2013 for the approval of the Methodological norms concerning the preparation of annual accounting reports for the informational needs of the Ministry of Public Finances, applicable to credit institutions, with incidental regulations that conform to the IFRS approved by the Order of NBR no. 27/2010, credit institutions draw up and present an annual accounting report containing the following forms: a) a statement of assets, liabilities and equity; b) profit and loss account; c) informative data; d) tangible and intangible assets; e) explanations of elements from the profit and loss account; f) other information.

The Ministry of Public Finances also prescribes, by means of order, the major aspects regarding the economic operators' preparation and presentation of annual financial statements and annual accounting reports at the territorial units of the MPF.

The categories of legal entities that apply - for the organisation and conducting of the accounting activity and the preparation of their annual financial statements accounting regulations that comply with the European directives are presented in the figure below.

\begin{tabular}{|c|c|}
\hline Categories of entities & Accounting regulation approved by \\
\hline $\begin{array}{l}\text { Economic operators, with the exception of } \\
\text { companies listed on the stock exchange }\end{array}$ & > Order of MPF no. 3055/2009 \\
\hline $\begin{array}{l}\text { Entities from the banking sector, besides } \\
\text { credit institutions }\end{array}$ & > Order of NBR no. $27 / 2011$ \\
\hline Entities from the sector of capital markets & > Order of NSC no. $13 / 2011$ and no. $12 / 2011$ \\
\hline Entities from the sector of insurance & $\begin{array}{l}\text { Order of Insurance Supervisory Commission } \\
\text { (ISC) no. } 3129 / 2005\end{array}$ \\
\hline Entities from the sector of private pensions & $\begin{array}{l}\text { Norm 14/2007 approved by Order of } \\
\text { Supervisory Commission of Private Pensions } \\
\text { System(SCPPS) no. } 37 / 2007\end{array}$ \\
\hline Non-profit legal entities & Order of MPF no. 1969/2007 \\
\hline Public institutions & Order of MPF no. 1917/2005 \\
\hline
\end{tabular}

Figure 1 Accounting regulations in compliance with the European Directives Source: own compilation 


\section{Requirements concerning interim financial reporting in Romania}

Besides the requirement of drawing up annual financial statements, for certain categories of entities, reporting obligations are also required for periods other than the annual reporting, throughout the financial year, in order to provide the information that is necessary for the institutional system of the state, for prudential supervisory or informative purposes that satisfy the needs of categories of users other than state institutions.

\section{Interim accounting reporting intended for the institutional system of the state}

As stipulated by Accounting law no. 82/1991 (Art. 28, al. 2), republished, with subsequent amendments and additions, in order to provide the information intended for the institutional system of the state, the Ministry of Public Finances can prescribe that entities have the obligation to prepare and present financial statements or accounting reports at the territorial units of the Ministry of Public Finances in periods other than per annum, throughout the financial year.

In the present, in Romania, such reporting requirements refer to half-yearly accounting reporting. The obligation of presenting a half-yearly accounting report on the $30^{\text {th }}$ of June applies only to certain categories of entities. For economic operators, the requirements of half-yearly reporting are regulated by annual order of the Ministry of Public Finances. The other categories of entities draw up and present half-yearly accounting reports respecting the format and due dates prescribed in the regulations issued by the NBR for the banking sector and by the FSA for each of the following three domains: insurance, insurance-reinsurance and reinsurance, the private pension system, capital markets domain, with the approval of MPF. As in the case of annual reporting, entities that did not operate from the date of their establishment until the date of the reporting, as well as entities that are undergoing liquidation, are required to present a declaration on oath at the regulatory organism as well as at the territorial units of MPF, without preparing half-yearly accounting reports.

An overview of the current regulations that prescribe the requirements for interim (half-yearly) accounting reporting for different types of entities includes:

\begin{tabular}{|c|c|}
\hline Acco unting entities & Regulation \\
\hline $\begin{array}{l}\text { Economic operators } \\
\text { (whose turnover in the preceding financial } \\
\text { year was higher than } 220.000 \text { lei) }\end{array}$ & > Order of MPF no. $936 / 2014$ \\
\hline Entities from the banking sector & Order of NBR no. $10 / 2012$ \\
\hline Entities from the capital markets sector & $\begin{array}{l}\text { Order of NSC no. } 70 / 2006 \text { for the } \\
\text { approval of Instruction no. } 5 / 2006\end{array}$ \\
\hline Entities from the insurance sector & - Norm FSA no. $18 / 2014$ \\
\hline - Entities from the private pension sector & $\begin{array}{l}\text { Decree of SCPPS no. } 12 / 2011 \text { for the } \\
\text { approval of Norm no. } 9 / 2011\end{array}$ \\
\hline
\end{tabular}

Figure 2 Regulations concerning the system of half-yearly accounting reporting Source: own compilation

Concerning the forms that constitute the contents of half-yearly accounting reporting, we observe that they are different for the various types of entities.

For economic operators (whose turnover in the preceding financial year was higher than 220.000 lei), by Order of MPF no. 936/2014, the models of forms used for half- 
yearly accounting reporting were established, for two categories of entities, the set of half-yearly financial statements having the following components:

- for entities that apply the accounting regulations in compliance with the European directives, approved by Order of MPF no. 3055/2009:
a) A statement of assets, liabilities and equity;
b) Profit and loss account;
c) Informative data.

- for entities that apply the accounting regulations in compliance with the IFRS, approved by Order of MPF no. 1286/2012:
a) A statement of assets, liabilities and equity;
b) Statement of revenue and expenditure;
c) Informative data.

Entities from the banking sector prepare half-yearly financial statements composed of a) a statement of assets, liabilities and equity; b) a profit and loss account and c) informative data, the models of reporting forms (approved by Order of NBR no. $10 / 2012$, with subsequent amendments and additions) being different for three types of entities: 1) credit institutions, 2) the deposit guarantee fund in the banking sector, 3) the other entities that are regulated by the NBR (non-bank financial institutions, payment institutions, institutions issuing electronic money etc.). These entities transmit their half-yearly financial statements to the territorial units of the MPF and to the NBR.

Entities from the capital markets sector which are authorized, regulated and supervised by the FSA - The Financial Instruments and Investments Sector draw up and present half-yearly financial statements prescribed by Instruction no. 5/2006 (approved by Order of NSC no. 70/2006, with subsequent amendments and additions) as presented in Figure 3.

\begin{tabular}{|l|c|}
\hline $\begin{array}{c}\text { Acco unting entities/ Compone nt forms for corresponding accounting } \\
\text { reports }\end{array}$ & Recipient \\
\hline $\begin{array}{l}\text { - Entities that are authorized, regulated and supervised by the NCS } \\
\text { (now FS A), with the excep tion of collective investment undertakings: } \\
\text { a) A statement of assets, liabilities and equity; } \\
\text { b) Profit and loss account; } \\
\text { c) Informative data. }\end{array}$ & $\begin{array}{r}\text { MPF } \\
\text { and } \\
\text { FSA }\end{array}$ \\
\hline $\begin{array}{l}\text { Collective investme nt undertakings which are established by } \\
\text { articles of association: } \\
\text { a) A statement of assets, liabilities and equity; } \\
\text { b) Profit and loss account; } \\
\text { c) Informative data. }\end{array}$ & MPF \\
and \\
\hline \hline $\begin{array}{l}\text { Collective investment undertakings which are not established by } \\
\text { articles of association: } \\
\text { a) A statement of assets, liabilities and equity; } \\
\text { b) Statement of revenue and expenditure. }\end{array}$ \\
\begin{tabular}{l} 
Note: Statements are prepared by the investment management firms \\
\hline
\end{tabular}
\end{tabular}

\section{Figure 3 Half-yearly financial reporting for entities from the capital markets sector \\ Source: own compilation}

Entities from the insurance sector that are authorized, regulated and supervised by the FSA - The Insurance-Reinsurance Sector draw up and transmit the set of half- 
yearly financial statements in compliance with Norm FSA no. 18/2014, both to the territorial units of the MPF and to the FSA, with the following components:

- For insurers and reinsurers:

a) Balance sheet;

b) Profit and loss account, composed of:

- Technical account for non-life insurance;

- Technical account for life insurance;

- Non-technical account.

c) Informative data.

- For insurance and/or reinsurance brokers:

a) Balance sheet;

b) Profit and loss account;

c) Informative data.

Mention should be made that insurers that administer voluntary pensions funds shall present financial statements for them, as well, and these are: a) A statement of assets, liabilities and equity; b) Statement of revenue and expenditure.

Entities from the private pensions sector that are authorized, regulated and supervised by the FSA - The Private Pensions System Sector draw up and present half-yearly financial statements prescribed by Norm no. 9/2011 (approved by Decree of SCPPS no. 12/2011, with subsequent amendments and additions), as presented in Figure 4.

\begin{tabular}{|l|l|}
\hline $\begin{array}{c}\text { Acco unting entities/ Compone nt forms for corresponding } \\
\text { accounting reports }\end{array}$ & Recipient \\
\hline $\begin{array}{l}\text { \% In the case of pensions companies: } \\
\text { a) A statement of assets, liabilities and equity; } \\
\text { b) Profit and loss account; } \\
\text { c) Informative data. }\end{array}$ & $\begin{array}{c}\text { FSA and MPF } \\
\text { and on the website of } \\
\text { the company }\end{array}$ \\
\hline \hline $\begin{array}{l}\text { In the case of pension funds, their managers draw up: } \\
\text { a) A statement of assets, liabilities and equity; } \\
\text { b) Statement of revenue and expenditure. }\end{array}$ & $\begin{array}{c}\text { Only FSA } \\
\text { and on the website of } \\
\text { the fund manager }\end{array}$ \\
\hline \hline $\begin{array}{l}\text { In the case of managers of voluntary pension funds, which } \\
\text { are insurance companies or investment manage ment firms; } \\
\text { for the administration of voluntary pension funds: } \\
\text { a) A statement of assets, liabilities and equity; } \\
\text { b) Statement of revenue and expenditure. }\end{array}$ & $\begin{array}{c}\text { Only FSA } \\
\text { and on the website of } \\
\text { the manager }\end{array}$ \\
\hline \hline $\begin{array}{l}\text { In the case of private pensions brokers: } \\
\text { a) A statement of assets, liabilities and equity; } \\
\text { b) Profit and loss account; } \\
\text { c) Informative data. }\end{array}$ & MPF and FSA \\
\hline \hline In the case of the guarantee fund: \\
$\begin{array}{l}\text { a) A statement of assets, liabilities and equity; } \\
\text { b) Profit and loss account; }\end{array}$
\end{tabular}

Figure 4 Half-yearly accounting reporting in the case of entities from the private pensions sector

Source: own compilation

The system of half-yearly accounting reporting includes the Methodological norms regarding the preparation, signing, verification and presentation of accounting reports as well as the informational contents of the forms used for accounting reporting. As 
in the case of annual financial statements, half-yearly financial statements provide comparative information concerning the following periods:

a) For the statement of assets, liabilities and equity/Balance sheet:

- A statement at the end of the reporting period (30 June $\mathrm{N}$ );

- A statement at the end of the preceding financial year (31.12.N-1).

b) For the Profit and loss account/ Statement of revenue and expenditure:

- A statement of revenue, expenditure and of the result of the reporting period (semester 1 , financial year $\mathrm{N}$ );

- A statement of revenue, expenditure and of the result of the comparative period from the preceding financial year(semester 1 , financial year $\mathrm{N}-1$ ).

The deadline for the presentation of half-yearly accounting reports is the same for all types of entities, for instance, the accounting reports as of June 302014 shall be presented at the territorial units of the MPF until the 18 of August 2014 at the latest.

As we can observe, half-yearly accounting reporting provides information related to the financial position, the financial performance as well as data concerning the other indicators contained by the reporting forms.

A different category of accounting entities is represented by public institutions, which have the obligation to draw up quarterly financial statements at the end of the $\mathrm{I}^{\mathrm{st}}$, II ${ }^{\text {nd }}$ and $\mathrm{III}^{\text {rd }}$ quarters, in compliance with the Methodological norms approved by Order of MPF no. 556/2014 and to present them at the MPF or at the hierarchically superior institutions, depending on the case. A set of quarterly financial statements has the following components:

a) Balance sheet;

b) Economic outturn account;

c) Statement of cash flows;

d) Budgetary execution accounts ${ }^{1}$;

e) Annexes (including accounting policies and explanatory notes).

Besides the requirement of publishing quarterly financial statements, public institutions also have to draw up some monthly financial reports.

Given their specific nature concerning subordination, public institutions should submit or present reports as follows:

- $\quad$ at the MPF: the chief authorising officers for the state budget, the social insurance budget and special funds budgets, as well as the public finances county administrations and the Public Finances General Regional Directorate of Bucharest for local budgets;

- at the hierarchically superior institutions: public institutions of central subordination whose leaders are secondary or tertiary authorised officers;

- at the public finances county administrations and the Public Finances General Regional Directorate of Bucharest: public institutions of local subordination whose leaders are chief authorised officers.

\section{Interim accounting reporting with prudential supervisory or informative purposes for satisfying the needs of users other than state institutions}

As we have shown above, entities which are authorized, regulated and supervised by the NBR or the FSA, depending on the case, have the obligation to present half-yearly accounting reports not only at the territorial units of the MPF but also at the regulating organism or, even more, on their web page. Besides these ones, other requirements are also formulated for interim reporting.

\footnotetext{
${ }^{1}$ Budgetary execution accounts differ depending on the category of the public institution, the financing modality and other criteria.
} 
For prudential supervisory or informative purposes that satisfy the needs of other categories of users, entities that belong to the sectors regulated by the NBR or the FSA are also required additional interim reports. Such reporting obligations for similar purposes are also required from companies that are listed on the stock exchange.

In accordance with the Regulation of NSC (now FSA) no. 1/2006 regarding the issuers and transactions with securities (Art. 113), companies whose shares are admitted for trading on a regulated market prepare, transmit and make public a series of quarterly, half-yearly and annual reports, as follows:

\begin{tabular}{|c|c|}
\hline Report & Components of the report \\
\hline $\begin{array}{l}\text { Quarterly report, } \\
\text { corresponding to the } \\
\text { first and the third } \\
\text { quarters }\end{array}$ & $\begin{array}{l}\checkmark \text { a profit and loss account prepared in accordance with the } \\
\text { applicable accounting regulations; } \\
\checkmark \text { economic - financial indicators (current liquidity, level of debt, } \\
\text { turnover ratio of client debits, tumover ratio of non-current assets). }\end{array}$ \\
\hline$\checkmark$ Half-yearly report & $\begin{array}{l}\text { an interim financial report in compliance with the IFRS } \\
\text { or } \\
\text { a simplified balance sheet, a simplified profit and loss account, as } \\
\text { the same principles as in the case of annual financial reports. } \\
\text { the with }\end{array}$ \\
\hline$\checkmark$ Anmual report & $\begin{array}{l}\checkmark \text { annual financial statements prepared in accordance with the } \\
\text { applicable accounting regulations. }\end{array}$ \\
\hline
\end{tabular}

Figure 5 Interim accounting reporting - entities listed on the stock exchange Source: own compilation

Companies whose securities are traded on a regulated market shall make public (in written form, on request, as well as in electronic form, on their own website) and shall transmit to the FSA and to the operator of the regulated market the annual financial statements as well as the half-yearly and quarterly accounting reports.

In the case of half-yearly reports the following rules shall also be respected:

- $\quad$ in case the issuer has to draw up consolidated accounts, the half-yearly accounting reporting shall be prepared in accordance with the international accounting standards that apply to interim financial reporting, adopted in compliance with the procedure prescribed by art. 6 . from the European Commission Regulation no. 1606/2002;

- $\quad$ in case the issuer does not have the obligation to draw up consolidated accounts, the half-yearly accounting reporting shall contain the simplified balance sheet and the simplified profit and loss account, as well as the annexed explanatory notes. For the drawing up of the simplified balance sheet and the simplified profit and loss account, the issuer shall respect the same principles as in the case of drawing up annual financial reports.

Credit institutions shall draw up and transmit to the NBR, for prudential supervisory purposes, periodical financial statements in compliance with the IFRS (referred to as FINREP financial statements) at an individual level (Order of NBR no. 3/2011) as well as FINREP consolidated financial statements (Order of NBR no. 1/2011). FINREP financial statements at an individual level, required from credit institutions with prudential supervisory purposes comprise two sets of information, namely, basic information (which is transmitted monthly) and information other than the basic type (that is transmitted monthly, quarterly, half-yearly or annually, depending on the case). Credit institutions submit/transmit FINREP financial 
statements at an individual level monthly, quarterly, half-yearly or annually, depending on the case, their structure and reporting frequency being as follows:

a) Basic information, with these components: FIN 1 Balance sheet and FIN 2 Profit and loss account, financial statements which are transmitted monthly;

b) Information other than the basic type, providing supplementary information and explanations on the indicators included in the basic information and which is transmitted monthly, quarterly, half-yearly or annually, depending on the case.

Entities from the capital market sector also have the obligation of transmitting halfyearly accounting statements to the regulatory authority (FSA), as shown in Figure no. 3. Moreover, if their titles are traded on a regulated market, these entities comply with the Regulation NSC no. 1/2006 regarding issuing institutions and transactions with securities and are obliged to present the required reports, too.

Entities from the insurance sector have the obligation of drawing up and submitting to the AFS a series of financial and technical reports, as well (annual, half-yearly, quarterly and monthly reports), whose form and contents are established by Order of ISC no. 2/2009 (in the case of insurance and/or reinsurance companies), and Order of ISC no. 3/2009 (in the case of insurance and/or reinsurance brokers), respectively. By means of these reports the required information is provided so that it allows the FSA to carry out a well grounded examination of the financial situation they benefit from at a certain moment and to monitor the evolution in time of the major indicators regarding the activity undertaken.

\section{Conclusions}

At the international level, the IFRS approach the subject concerning the presentation of financial statements with a general purpose (financial statements that are meant to satisfy the needs of the users that are not entitled to oblige an entity to draw up reports that are adapted to their specific informational needs), prescribe the components that should be included in a complete set of financial statements as well as the minimum components of an interim financial report, together with the principles for accounting recognition and measurement that should be applied for the drawing up of an interim financial report. In the case of interim financial reporting, the IFRS do not establish which entities should publish interim financial reports, how frequently or how soon after the end of an interim period, so the IASB considers that these problems should be decided at the level of each country by governments, organisms for the regulation of securities, stock exchanges and professional accountancy organisms.

In Romania, in order to provide the information that is necessary for the institutional system of the state, the MFP prescribes the obligation of preparing and presenting, at its territorial units, the financial statements or accounting reports for periods other than the annual reporting, throughout the financial year. Currently, the deadline for the obligation of drawing up a half-yearly accounting report is June 30 for certain categories of entities. At the same time, certain categories of entities are required to draw up and present financial statements (annual, half-yearly, quarterly and monthly, depending on the case), either for prudential supervisory purposes or for informative purposes in order to satisfy the needs of users other than state institutions.

\section{References}

CECCAR (2004), Ghid pentru înţelegerea şi aplicarea Standardului Internaţional de Contabilitate nr. 34 „Raportarea financiară interimară”, Bucharest, Editura CECCAR. 
Deloitte (2009), Interim financial reporting. A guide to IAS 34, March 2009, available at http://www.iasplus.com/en/binary/dttpubs/0903ias34guide.pdf.

Hotărârea CSSPP nr. 12/2011 pentru aprobarea Normei nr. 9/2011 privind sistemul de raportare contabilă semestrială a entităţilor autorizate, reglementate şi supravegheate de Comisia de Supraveghere a Sistemului de Pensii Private, with subsequent amendments.

IASB (2011), Standardele Internationale de Raportare Financiară (IFRSs). Norme oficiale emise la 1 ianuarie 2011, Partea A, Bucharest, Editura CECCAR.

Legea contabilităţii $n r$. 82/1991, republished, with subsequent amendments.

Norma ASF nr. 18/2014 pentru punerea în aplicare a Sistemului de raportare contabilă la 30 iunie 2014 a societăţilor din domeniul asigurărilor.

Ordinul BNR nr. 27/2010 pentru aprobarea Reglementărilor contabile conforme cu Standardele Internaţionale de Raportare Financiară, aplicabile instituţiilor de credit, with subsequent amendments.

Ordinul BNR nr. 1/2011 pentru aprobarea Normelor metodologice privind întocmirea situaţiilor financiare consolidate conforme cu Standardele Internaţionale de Raportare Financiară, solicitate instituţiilor de credit în scopuri de supraveghere prudenţială.

Ordinul BNR nr. 3/2011 pentru aprobarea Normelor metodologice privind întocmirea situaţiilor financiare FINREP la nivel individual, conforme cu Standardele internaţionale de raportare financiară, aplicabile instituţiilor de credit în scopuri de supraveghere prudenţială.

Ordinul BNR nr. 10/2012 pentru aprobarea Sistemului de raportare contabilă semestrială aplicabil entităţilor ce intră în sfera de reglementare contabilă a BNR, with subsequent amendments.

Ordinul BNR nr. 1/2013 pentru aprobarea Normelor metodologice privind întocmirea raportării contabile anuale pentru necesităţi de informaţii ale Ministerului Finanţelor Publice, aplicabile instituţiilor de credit, cărora le sunt incidente reglementările conforme cu IFRS aprobate prin Ordinul BNR nr. 27/2010.

Ordinul CNVM nr. 23/2006 pentru aprobarea Regulamentului CNVM nr. 1/2006 privind emitenţii şi operaţiunile cu valori mobiliare, with subsequent amendments.

Ordinul CNVM nr. 70/2006 pentru aprobarea Instrucțiunii nr. 5/2006 cu privire la sistemul de raportare contabilă semestrială a entităţilor autorizate, reglementate şi supravegheate de CNVM, with subsequent amendments.

Ordinul MFP nr. 1286/2012 pentru aprobarea Reglementărilor contabile conforme cu Standardele Internaţionale de Raportare Financiară, aplicabile societăţilor comerciale ale căror valori mobiliare sunt admise la tranzacţionare pe o piaţă reglementată, with subsequent amendments.

Ordinul MFP nr. 556/2014 pentru aprobarea Normelor metodologice privind întocmirea şi depunerea situaţiilor financiare trimestriale ale instituţiilor publice, precum şi a unor raportări financiare lunare în anul 2014.

Ordinul MFP nr. 936/2014 pentru aprobarea Sistemului de raportare contabilă la 30 iunie 2014 a operatorilor economici.

Rotilă, A. (2011), Reglementări şi practici contabile specifice, Bacău, Editura Alma Mater. 